\title{
EFEKTIVITAS TERAPI SPRITUAL SHALAT DAN DZIKIR TERHADAP KONTROL DIRI KLIEN PENYALAHGUNAAN NAPZA
}

\author{
Akhmad $^{1}$, Askrening $^{2}$, Indriono Hadi ${ }^{3}$, Ismail $^{4}$ \\ ${ }^{1}$ Jurusan Keperawatan, Poltekkes Kemenkes Kendari, Indonesia: akhmadjurkep@gmail.com \\ 2 Jurusan Gizi, Poltekkes Kemenkes Kendari, Indonesia: askreningrennyi@gmail.com \\ ${ }^{3}$ Jurusan Keperawatan, Poltekkes Kemenkes Kendari, Indonesia: indrionohadi@gmail.com \\ ${ }^{4}$ Jurusan Keperawatan, STIKes Karya Kesehatan Kendari: Indonesia. \\ (Korespondensi e-mail: akhmadjurkep@gmail.com)
}

\begin{abstract}
ABSTRAK
Agama adalah salah satu faktor perlindungan yang memberikan hasil positif dengan mencegah individu terlibat dalam penyalahgunaan Napza. Agama dan spritual dapat menghambat kecanduan, dan menjaga kontrol diri klien penyalahgunaan Napza. Narkotika yang digunakan secara terus menerus akan mengakibatkan toleransi yang cukup tinggi, dan jika pemakaian dihentikan maka akan menimbulkan with drawl atau sindroma putus zat. Penyembuhannya dengan cara rehabilitasi medis maupun non medis, rehabilitasi non medis salah satunya dengan teknik terapi spiritual termasuk shalat dan zikir muncul sebagai metode terapi spiritual Islam yang berlaku yang dilakukan dengan cara mendekatkan diri klien terhadap spritual dan agama yang dianutnya. Pretest hasil pengukuran 16 responden memiliki kontrol diri negatif dan 12 responden memiliki kontrol diri positif, kemudian setelah diberikan perlakuan terapi shalat dan dzikir selama dua bulan pengukuran kontrol diri positif 26 responden dan 2 responden kontrol diri negatif. Uji statistik Mc Nemar nilai $\mathrm{p}<0.001$ kurang dari nilai $\alpha 0.05$, yang berarti terdapat pengaruh pemberian terapi shalat disertai dzikir terhadap kontrol diri klien penyalahgunaan NAPZA.
\end{abstract}

Kata kunci: Dzikir, Kontrol Diri, Napza, Shalat, Spritual

\section{Abstract}

Religion is one of the protection factors that gives positive results by preventing individuals from being involved in drugs abuse. Religion and spiritual can inhibit addiction and keep self-control of Napza's abuse clients. Narcotics used continuously will lead to high tolerance, and if the use is discontinued it will cause with drawl or discontinuous syndrome. The treatment of medical and non-medical rehabilitation, nonmedical rehabilitation, one of which has spiritual therapy techniques including prayer and remembrance, emerged as a method of Islamic spiritual therapy in effect by bringing clients closer to their spiritual and religion. Pretest results of the measurement of 16 respondents had the negative self-control and 12 respondents had the positive selfcontrol, then after given the treatment of prayer and dhikr therapy for two months of measurement of the positive self-control 26 respondents and 2 respondents negative selfcontrol. Statistical test Mc Nemar's the value of P. $<0.001$ is less than $\alpha 0.05$, which means that there is the influence of prayer therapy accompanied by a dhikr against the self-control of DRUG abuse.

Keywords: Dhikr, Napza, Prayer Therapy, Self-Control, Spiritual 


\section{PENDAHULUAN}

Penyalahgunaan NAPZA (Narkotika, Alkohol, Psikotropika dan zat Adiktitif) adalah penggunaan NAPZA yang bersifat patologis, jika berlangsung 1 bulan lamanya akan menimbulkan gangguan dalam pekerjaan dan fungsi sosial. penyalahgunaan NAPZA yang menetap dalam jumlah berlebihan, secara berkala atau terus menerus, berlangsung cukup lama akan menyebabkan terjadinya ketergantungan pada pemakai sehingga menyebabkan banyak gangguan fisik, dan psikologis, merugikan kesehatan jasmani mental dan kehidupan sosial (Zan \& Bethsaida, 2011).

Islam merupakan agama terbesar di dunia memiliki ajaran yang berpengaruh meningkatkan kesehatan fisik dan mental jika diamalkan. Sebagian besar literatur mengakui agama dan spritual sebagai korelasi penting dari sebuah terpi kesembuhan. Dalam sebuah penelitian dengan terapi spritual dalam empat minggu menunjukkan efek yang lebih besar untuk mengurangi skala gejala psikologis dan menunjukkan peningkatan dan peningkatan dalam aspek ketulusan, kesabaran, penerimaan penyakit, motivasi, antusiasme, dan kemampuan kerja sama dengan petugas kesehatan dan lingkungan kemampuan dalam pengendalian diri selama program pelatihan (Khalid, 2008; Rosyanti et al., 2019; Rosyanti, Hadju, Hadi, \& Syahrianti, 2018; Zan \& Bethsaida, 2011).

Selain itu, terapi spritual sangat efektif sebagai terapi pelengkap untuk pasien adiktif dan skizoprenia, diharapkan menjadi intervensi spiritual sebagai sebuah prosedur perawatan medis komplementer termasuk kecanduan narkoba. Agama adalah salah satu faktor perlindungan yang diidentifikasi sebagai memfasilitasi hasil positif dengan melindungi individu dari konstruksi yang menempatkan mereka pada risiko terlibat dalam zat dan praktik kecanduan Pekerjaan yang lebih baru terus mengkonfirmasi bahwa agama menghambat kecanduan narkoba (Khalid, 2008; Piko \& Fitzpatrick,
2004; Rosyanti, Hadi, et al., 2018; Seghatoleslam et al., 2015).

Individu yang pulih dari kecanduan sering menyatakan bahwa spiritualitas membantu dalam proses penyembuhan. Namun, masih sedikit yang diketahui tentang bagaimana spiritualitas dapat dimasukkan ke dalam perawatan formal terhadap perbedaan individu. Dalam sebuah penelitian untuk mengetahui bagaimana peran spiritualitas dalam pemulihan dan kesesuaiannya dalam perawatan formal. Analisis tematik menunjukkan bahwa spiritualitas dan praktik keagamaan berperan dengan cara yang kompleks selama kecanduan seiring dengan pemulihan. Lebih disukai dan sesuai dalam perawatan formal dengan pendekatan spritual daripada alternatif yang tersedia, karena membantu individu narkoba dengan intervensi berbasis spiritual dalam pengaturan perawatan formal (Heinz et al., 2010).

Salah satu tujuan agama adalah untuk memfasilitasi perkembangan spiritualitas anggotanya, konsep yang lebih individual yang dicirikan oleh hubungan pribadi dengan sesuatu yang transenden atau melampaui diri. Meskipun tingkat religiositas dan spiritualitas yang lebih tinggi telah dikaitkan dengan kesehatan fisik dan mental yang lebih besar, peran kerohanian dalam memfasilitasi hasil perawatan kecanduan yang berhasil baru-baru ini diidentifikasi sebagai area yang berpotensi penting bagi penelitian dan praktik klinis kecanduan (Cook, 2004; Miller, 1998).

Meskipun kurangnya penelitian di bidang ini, spiritualitas telah terbukti menjadi prediktor yang signifikan dan independen untuk pemulihan dan/atau peningkatan dalam indeks hasil pengobatan. Tingkat spiritualitas meningkat antara masuknya pengobatan dan pemulihan selanjutnya, dan tingkat kerohanian lebih besar pada individu yang pemulihannya berhasil dibandingkan dengan mereka yang mengalami kekambuhan. Ketenangan juga telah dikaitkan secara positif dengan spiritualitas sementara komitmen terhadap 
kekuatan yang lebih tinggi dapat mengurangi keparahan episode kambuh pasien ketegantunagn Napza. (Fiorentine \& Hillhouse, 2000; Flynn, Joe, Broome, Simpson, \& Brown, 2003; Pardini, Plante, Sherman, \& Stump, 2000; Piedmont, 2004).

Dalam studi retrospektif, pecandu yang sembuh sering melaporkan spritual/kerohanian sebagai komponen penting dari upaya pemulihan mereka dan untuk membantu mempertahankan perubahan yang dibuat selama perawatan. Selain itu, program yang berorientasi spiritual seperti Narcotics Anonymous (NA) dan Alcoholics Anonymous (AA) sangat populer, terutama di Amerika Serikat, dan meskipun sangat sulit untuk menilai efektivitas program tersebut dalam inkarnasi naturalistik mereka, dapat menjadi bukti adanya efektiftivitas perbaikan di bidang soritual dan agama. Dengan adanya temuantemuan tersebut, akan sangat bermanfaat untuk terapi dengan adanya perubahan perilaku berdasarkan spiritual/agama untuk memfasilitasi kontrol diri dan mencegah kekambuhan (Fiorentine \& Hillhouse, 2000; Flynn et al., 2003; Pardini et al., 2000; Piedmont, 2004).

Meskipun sedikit yang diketahui tentang aspek-aspek religiusitas dan spiritualitas yang dapat memengaruhi pemulihan dari kecanduan, beberapa studi menunjukkan bahwa keterampilan mengatasi yang diperoleh melalui agama dan spiritualitas merupakan sumber daya perawatan yang kurang dimanfaatkan. Dalam sebuah penelitian pengguna narkoba suntikan HIV-positif dan HIV-negatif yang berpartisipasi dalam kelompok penelitian, melaporkan bahwa kerohanian adalah sumber kekuatan batin dan bahwa intervensi spiritual akan membantu untuk mengurangi "ketergantungan dan keinginan" dan perilaku berisiko HIV, mengikuti rekomendasi medis, dan meningkatkan harapan pecandu yang pulih. Dalam penelitian tersebut dengan menilai intervensi berbasis spiritual pada penguna napza didapatkan adanya dukungan kuat untuk terapi spiritualitas ke dalam pengobatan (Arnold, Avants, Margolin, \& Marcotte, 2002).

Beberapa Studi deskriptif menunjukkan beberapa pasien yang menggunakan zat melaporkan bahwa spiritualitas adalah pusat kehidupan serta pemulihan mereka. Persepsi dokter tentang kebutuhan spiritual pasien kadang-kadang tampak tidak akurat. Dalam sebuah penelitian terhadap 101 pasien dan penyedia mereka pada program perawatan, menemukan bahwa staf keperawatan mengabaikan tingkat kerohanian pasien dan pentingnya pasien di terapi spiritualitas dalam proses pemulihan; Beberapa mahasiswa kedokteran yang bertanggung jawab mengobati penggunaan narkoba secara signifikan kurang religius daripada pasien yang mereka rawat, cenderung tidak memandang agama atau spiritualitas sebagai aspek signifikan dari perawatan pasien, dan mengabaikan tingkat spiritualitas pasien sebagai aspek penting dari substansi perawatan. Perbedaan pandangan antara tenaga kesehatan dan pasien mengenai pentingnya spiritualitas dalam perawatan dapat menghambat penggabungan spiritualitas ke dalam perawatan (Heinz et al., 2010; McDowell, Galanter, Goldfarb, \& Lifshutz, 1996).

Shalat ialah ibadah yang terdiri dari perkataan dan perbuatan tertentu yang dimulai dengan membaca takbir bagi Allah dan disudahi dengan mengucap salam. Berdzikir kepada Allah adalah ibadah sunnah yang teramat mulia. Dzikir adalah doa yang paling tinggi, yang di dalamnya tersimpan berbagai keutamaan dan manfaat yang besar bagi hidup dan kehidupan seseorang muslim (Ardani, 2008; Syabiq).

Sholat adalah segala perkataan dan perbuatan yang diawali dengan takbiratul ikhram dan yang diakhiri dengan salam, dan wajiblah mengerjakan itu pada waktu-waktu tertentu. Sholat ialah berhadap hati kepada Allah sebagai ibadat, dalam bentuk beberapa perkataan dan perbuatan yang diawali dengan takbir dan di akhiri dengan salam 
serta menurut syarat-syarat yang telah di tentukan oleh syar'i. Karena sholat itu adalah merupakan pokok (yang utama) dari agama Islam. Sebagaimana sabda Nabi Saw. yang artinya sebagai berikut "sholat itu adalah tiang daripada agama, maka barang siapa yang mendirikannya, maka berarti ia telah mendirikan agama. Dan barang siapa meninggalkannya, berarti ia telah merbohkan agama" (Baqi \& Fu'ad, 2012; Suhardi, 2002).

Di dalam sholat seseorang mukmin dapat merasakan ketenangan serta ketentraman hidup. Karena sesungguhnya ia memulai sholatnya dengan mengucapkan "'Allahu Akbar". dimana ia telah menyadari sepenuhnya bahwa Allah itu Maha Besar kemudian ia membaca surat Al-Fatihah, ia jumpai didalamnya sesuatu kesegaran batin yang didambakan dan menjumpai perasaan yang penuh keyakinan akan adanya bimbingan ke jalan yang lurus dan dijauhkannya dari jalan yang sesat serta jalan yang dimurkai-Nya. Sholat itu memberikan suatu ketenangan, kedamaian hidup dan kekuatan batin, bagi orang yang mengerjakannya. Rasulullah Saw telah menjelaskan tentang pengaruh kejiwaan yang dicapai lewat sholat. wudhu dan dzikrullah. Yaitu menjadikan kekuatan, kesegaran dan semangat pada seorang mukmin yang mengerjakan sholat, didalam menghadapi kesehariannya setiap pagi (Hussein; Osama \& Malik, 2019; Suhardi, 2002).

Berdasarkan data BNN Provinsi Sulawesi Tenggara tahun 2015 terdapat sebanyak 628 pengguna narkoba, pada tahun 2016 terjadi penurunan yang cukup signifikan yaitu sebanyak 585 pengguna narkoba. Berdasarkan hasil wawancara dengan salah satu petugas BNN Provinsi Sulawesi Tenggara bahwa pengguna narkoba pada kasus penyalahgunaan narkoba terdapat pengguna lama yang sudah pernah menjalani rehabilitasi, kemudian kembali menjalani rehabilitasi karena menggunakan kembali. Penggunaan berulang inilah yang mengganjal, kenapa bisa orang yang sudah pernah di rehabilitasi kembali mengkomsumsi narkoba, apakah tidak ada pengaruh dari pemberian terapiterapi sebelumnya.

Berdasarkan hasil Monitoring dan Evaluasi Program Rehabilitasi Pengguna Narkoba di Lapas Kelas II A Kendari khusus untuk pelayanan rawat inap tahun 2015 sebanyak 91 orang dan mengalami perubahan yang signifikan di tahun 2016 sebanyak 85 orang dengan kasus terbanyak berada pada kelompok usia 25-34 tahun sebanyak 56 orang, kemudian kelompok usia 20-24 tahun sebanyak 10 orang, kelompok usia 40-44 tahun sebanyak 9 orang, kelompok usia 35-39 tahun 6 orang dan kelompok usia $>45$ tahun 4 orang. Kegiatan rutin yang dilakukan oleh petugas di Lapas Kelas II A Kendari untuk pelayanan rehabilitasi, dengan melakukan pemeriksaan urine sebanyak 3 kali dalam waktu $3 x$ sebulan. Dan berdasarkan hasil wawancara dengan salah satu petugas Lapas Kelas II A Kendari mengatakan bahwa pengguna narkoba yang menjalani rehabilitasi terkadang masih mengalami gangguan kontrol diri dimana terkadang klien mudah tersinggung, marah dan berprilaku kasar.

Keterkaitan antara kontrol diri dengan penyalahgunaan narkotika telah diteliti dan menghasilkan adanya hubungan bahwasanya semakin tinggi kontrol diri maka perilaku penyalahgunaan narkotika semakin menurun, permasalahan itulah yang diangkat dalam penelitian ini. Subjek dalam penelitian ini adalah klien penyalahgunaan narkotika di Lapas Kelas II A Kendari, berdasarkan hasil observasi dan wawancara yang dilakukan pra eksperimen, didapatkan hasil dari sekian subjek mengalami hal yang sama, penyebab menggunakan narkotika dikarenakan ketidakmampuan dalam mengontrol diri yang ditandai dengan sulit dalam menjaga dan mengontrol pikiran dan keinginan untuk kembali mengkonsumsi narkotika, emosi yang labil, merasa tidak bergairah dalam menjalani hidup dan tidak yakin bisa berhasil dalam menghadapi masa depan, ada beberapa yang kadang masih 
merasa sakau, walaupun dalam kontek yang berbeda-beda. Hal ini nantinya akan diteliti lebih lanjut dengan pengukuran kontrol diri klien sebelum melakukan eksperimen.

Kontrol diri merupakan suatu kecakapan individu dalam kepekaan membaca situasi diri dan lingkungannya. Selain itu, juga kemampuan untuk mengontrol dan mengelola faktor-faktor perilaku sesuai dengan situasi dan kondisi untuk menampilkan diri dan melakukan sosialisasi kemampuan untuk mengendalikan perilaku, kecenderungan menarik perhatian, keinginan mengubah perilaku agar sesuai dengan orang lain, menyenangkan orang lain, selalu conform dengan orang lain, dan menutupi perasaannya (Ghufron \& Risnawita, 2010).

Kontrol diri adalah keterampilan, bukan sifat karakter. Ini adalah sesuatu yang Anda mulai, praktikkan, dan kembangkan dengan membiasakan diri mengendalikan perilaku Anda. Anda mungkin dilatih dengan baik untuk menyerah pada desakan, tetapi Anda mungkin tidak dilatih secara mandiri. Tidak ada keajaiban untuk mengendalikan diri, hanya kegigihan dan latihan. Berita baiknya adalah bahwa pengendalian diri adalah sesuatu yang Anda miliki untuk meningkatkan kemampuan. Kontrol diri didefinisikan sebagai suatu jalinan yang secara utuh atau terintegrasi antara individu dengan lingkungannya. Individu yang memiliki kontrol diri tinggi berusaha menemukan dan menerapkan cara yang tepat untuk berperilaku dalam situasi yang bervariasi. Kontrol diri mempengaruhi individu untuk mengubah perilakunya sesuai dengan situasi sosial sehingga dapat mengatur kesan lebih responsif terhadap petunjuk situasional, fleksibel, dan bersikap hangat serta terbuka (Maisto \& Caddy, 1981).

\section{METODE}

\section{Jenis Penelitian}

Penelitian ini menggunakan desain penelitian quasy experiment dengan menggunakan pendekatan pre and post test design.

\section{Lokasi dan Waktu Penelitian}

Penelitian ini telah dilaksanakan pada bulan Januari-Juni 2017, dilaksanakan di Lapas Kelas II A Kendari.

\section{Populasi dan Sampel.}

Populasi dalam penelitian ini adalah seluruh klien penyalahgunaan NAPZA yang ada di Lapas Kelas II A Kendari yang beragama islam, yang mengetahui bacaan shalat dan dzikir, yang berada dalam tahap rehabilitasi ketiga, sedangkan sampelnya terdapat 28 orang yang berada dalam tahap rehabilitasi ke 3 yang sesuai kriteria inklusi.

\section{Pengumpulan Data}

Teknik penarikan sampling dalam penelitian ini menggunakan teknik nonprobability. Metode pengumpulan data yang digunakan dalam penelitian ini adalah:

1. Kuisioner skala kontrol diri. Skala pengendalian diri yang dipakai dalam penelitian ini merupakan skala pengendalian diri yang di adaptasi dari penelitian Nur Lailatul Muniroh tahun 2013 dengan menggunakan teori dari Averill, yang telah teruji validitas dan reliabilitasnya. Skala ini akan dipakai untuk pre-test dan post-test, guna mengukur tingkat pengendalian diri klien rehabilitasi narkotika sebelum dan sesudah dilakukannya perlakuan.

2. Observasi. Observasi diarahkan pada kegiatan memperhatikan secara akurat, mencatat fenomena yang muncul, dan mempertimbangkan hubungan antar aspek dalam fenomena tersebut. Observasi yang berarti pengamatan bertujuan untuk mendapatkan data tentang suatu masalah, sehingga diperoleh pemahaman atau sebagai alat rechecking atau pembuktian terhadap informasi/keterangan yang diperoleh sebelumnaya. Observasi dilakukan untuk menggali data kualitatif mengenai dinamika perilaku subjek 
selama menjalani terapi. Observasi dan wawancara perlu dilakuka untuk mendapatkan data kualitatif, yang digunakan untuk membantu analisis data hasil penelitian. Dalam penelitian ini obserasi yang dilakukan adalah mengamati responden dalam menjalankan ibadah shalat dan dzikir.

3. Dokumen. Dokumen didapat dari lembaga tempat rehabilitasi untuk mengetahui beberapa keterangan yang dibutuhkan guna penelitian ini, keterangan yang dibutuhkan dalam dokumen tersebut adalah daftar pasien penyalahgunaan narkotika.

4. Pengumpulan data. Tahap pertama adalah peneliti mengurus surat ijin untuk melakukan penelitian pada bagian akademik Prodi S1 Keperawatan dan pihak LAPAS Kelas II A Kendari. Kemudian menjelaskan tentang maksud dan tujuan pada responden dan sekaligus memberikan lembar informed consent dan lembar persetujuan menjadi responden. Peneliti kemudian mempersiapkan alat/instrument yang akan digunakan dalam pengumpulan data seperti lembar observasi. Setelah pengumpulan data selesai, data akan diolah dengan langkah mulai dari editing, coding, scoring, sampai entry data. Kemudian dilakukan uji statistik, kemudian diambil kesimpulan. Pemberian terapi dilakukan pada tempat yang tenang dan nyaman, teknik yang digunakan dengan metode wawancara terstruktur dan observasi.

Beberapa instrumen penelitian yang dipakai dalam penelitian ini adalah sebagai berikut:

1. Skala Kontrol Diri. Skala kontrol diri adalah instrumen pengukuran tingkat pengendalian diri, berisi 36 pernyataan yang diadaptasi dari teori
Averil, dimana responden menetukan jawaban dari pernyataan sesuai dengan keadaan dirinya, dengan memberi tanda silang (X) pada pilihan jawaban $\mathrm{SS}=$ sangan setuju, $\mathrm{S}=$ setuju, TS = tidak setuju, STS $=$ sangan tidak setuju. Skala kecemasan ini terdiri atas 18 pernyataan unfavourable dan 18 pernyataan favourable. Setiap pernyataan favourable bernilai SS = $4, \mathrm{~S}=3, \mathrm{TS}=2, \mathrm{STS}=1$. Pada pernyataan unfavourable bernilai SS $=1, \mathrm{~S}=2, \mathrm{TS}=3, \mathrm{STS}=4$ (Averill, 1973; Nęcka, 2015; Unger, Bi, Xiao, \& Ybarra, 2016)

2. Lembar monitoring terapi. Lembar monitoring digunakan untuk mengontrol subjek penelitian dalam melakukan terapi, setiap melakukan terapi subjek akan didata dalam lembar monitoring terapi. Keterangan yang digunakan adalah $\mathrm{S}$ $=$ Shalat $\mathrm{D}=$ Dzikir, cara pengisiannya dengan memberi tanda ceklis pada kolom $\mathrm{S}$ apabila telah melakukan shalat, dan beritanda ceklis pada kolom D apabila telah melakukan Dzikir.

Terapi religi yang dilakukan sebagai suatu bentuk perlakuan, dilakukan dalam dua sesi terapi shalat dan terapi Dzikir. Terapi dilakukan selama dua bulan dan responden akan dipantau dalam melakukan ibadah shalat dan dzikir. Dalam pelaksanaannya terapi, sebelum melakukan terapi diawal sesi responden akan diberikan penyuluhan tentang keutamaan dan manfaat dari shalat dan Dzikir terhadap kesehatan sfisik dan mentalnya. Pelaksanaan terapi selama dua bulan, responden menjalankan ibadah shalat dengan.

Deskripsi posisi shalat sebagai berikut: shalat diawali dengan takbir, yaitu gerakan mengangkat tangan setingkat wajah seseorang sehingga ibu jari menyentuh lobulus telinga. Kemudian diikuti oleh Berdiri (qiyam) hingga 60-90 detik, diikuti 
dengan rukuk 5-10 detik, dan kemudian berdiri lagi selama 2-5 detik. Kemudian, responden bergerak dari berdiri ke sujud selama 5-10 detik, diikuti dengan duduk (tahiyyat) selama 2-5 detik, dan kemudian kembali ke sujud 5- 10 detik, diikuti dengan duduk (tahiyyat) selama 20-30 detik. Semua kegiatan ini adalah satu sebuah Rakat, dan tindakan Salat dapat terdiri dari 2-4 rakat. Pada akhir shalat, responden memutar kepala ke kedua bahu, pertama kanan dan kiri (Osama \& Malik, 2019).

Setelah itu melakukan dzikir yang akan dimonitoring setiap harinya. Dzikir yang diberikan berupa:

1. Membaca tasbih (33x) سُبْحَانَ الله

2. Membaca tahmid (33x) آنْحَنْدُدُ لله

3. Membaca takbir (33x) الله أَكْبَهِ

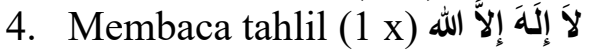

Perlakuan (treatment) berupa terapi shalat dan dzikir yang diberikan kepada kelompok eksperimen dengan cara, meminta mereka melakukan shalat wajib 5 waktu ditambah dzikir, seperti shalat dan zikir tuntunan alquran dan sunnah. Di awal sesi di berikan skala kontrol diri sebagai pretest dan pada ahir terapi diberikan skala kontrol diri sebagai posttest, untuk mengetahui adakah pengaruh shalat dan dzikir terhadap kontrol diri. (Hidayati, 2014; Mudzkiyyah, Nashori, \& Sulistyarini, 2014; Rosyanti et al., 2019; Rosyanti, Hadju, et al., 2018).

\section{HASIL}

\section{Karekteristik Responden}

Tabel 1. Distribusi Berdasarkan Usia

\begin{tabular}{ccc}
\hline \multirow{2}{*}{ Kelompok Umur } & \multicolumn{2}{c}{ Jumlah } \\
\cline { 2 - 3 } & $\mathrm{n}$ & $\%$ \\
\hline $17-25$ & 3 & 10,8 \\
$26-35$ & 16 & 57,1 \\
$36-45$ & 7 & 25,0 \\
$46-55$ & 2 & 7,1 \\
\hline Total & 28 & 100 \\
\hline
\end{tabular}

Distribusi responden menurut umur tertinggi usia 26-35 tahun (Masa dewasa awal) sebanyak 16 orang $(57,1 \%)$, dan terendah usia 46-55 tahun (masa lansia awal) sebanyak 2 orang $(7,1 \%)$.
Tabel 2. Distribusi Berdasarkan Pendidikan

\begin{tabular}{ccc}
\hline \multirow{2}{*}{ Tingkat Pendidikan } & \multicolumn{2}{c}{ Jumlah } \\
\cline { 2 - 3 } & $\mathrm{n}$ & $\%$ \\
\hline SD & 2 & 7,1 \\
SMP & 4 & 14,4 \\
SMA & 20 & 71,4 \\
S1 & 2 & 7,1 \\
\hline Total & 28 & 100 \\
\hline
\end{tabular}

Distribusi responden berdasarkan tingkat Pendidikan, tertinggi berpendidikan SMA sebanyak 20 orang $(71,4 \%)$, dan yang terendah berpendidikan SD dan S1 masing 2 orang $(7,1 \%)$.

$\underline{\text { Tabel 3. Distribusi Berdasarkan Pekerjaan }}$

\begin{tabular}{ccc}
\hline \multirow{2}{*}{ Jenis Pekerjaan } & \multicolumn{2}{c}{ Jumlah } \\
\cline { 2 - 3 } & $\mathrm{n}$ & $\%$ \\
\hline Driver & 3 & 10,7 \\
PNS & 1 & 3,6 \\
Swasta & 16 & 57,1 \\
Tani & 1 & 3,6 \\
Wiraswasta & 7 & 25,0 \\
\hline
\end{tabular}

Distribusi responden, tertinggi pada pekerja swasta sebanyak 16 orang $(57,1 \%)$, dan terendah pada Tani 1 orang $(3,6 \%)$ dan PNS sebanyak 1 orang $(3,6 \%)$.

Tabel 4. Distribusi Berdasarkan Masa Tahanan

\begin{tabular}{ccc}
\hline \multirow{2}{*}{ Masa Tahanan } & \multicolumn{2}{c}{ Jumlah } \\
\cline { 2 - 3 } & $\mathrm{n}$ & $\%$ \\
\hline 4 tahun & 6 & 21,4 \\
4 tahun 2 bulan & 1 & 3,6 \\
4 tahun 3 bulan & 4 & 14,3 \\
4 tahun 6 bulan & 1 & 3,6 \\
5 tahun & 3 & 10,7 \\
5 tahun 2 bulan & 1 & 3,6 \\
5 tahun 3 bulan & 3 & 10,7 \\
5 tahun 6 bulan & 4 & 14,3 \\
6 tahun & 1 & 3,6 \\
6 tahun 3 bulan & 1 & 3,6 \\
7 tahun 5 bulan & 1 & 3,6 \\
8 tahun 3 bulan & 1 & 3,6 \\
9 tahun 6 bulan & 1 & 3,6 \\
\hline Total & 28 & 100 \\
\hline
\end{tabular}

Distribusi responden berdasarkan masa tahanan, tertinggi masa tahanan 4 tahun sebanyak 6 orang $(21,4 \%)$

Analisis Univariat

Hasil Pengukuran Kontrol Diri Pre Test 
Tabel 4. Kontrol Diri Klien Sebelum Terapi Therapy Shalat dan Dzikir

\begin{tabular}{lcc}
\hline \multirow{2}{*}{ Kontrol diri pre test } & \multicolumn{2}{c}{ Jumlah } \\
\cline { 2 - 3 } & $\mathrm{f}$ & $\%$ \\
\hline Positif & 12 & 42,86 \\
Negatif & 16 & 57,14 \\
\hline
\end{tabular}

Hasil analisis menunjukkan ada 16 responden $(57,14 \%)$ yang memiliki kontrol diri negatif dan 12 responden $(42,86 \%)$ yang memiliki kontrol diri positif.

\section{Hasil Pengukuran Kontrol Post Tes}

Tabel 5. Kontrol Diri Klien Setelah Pemberian Terapi Shalat dan Dzikir

\begin{tabular}{lcc}
\hline \multirow{2}{*}{ Kontrol diri post test } & \multicolumn{2}{c}{ Jumlah } \\
\cline { 2 - 3 } & f & $\%$ \\
\hline Positif & 26 & 92,86 \\
Negatif & 2 & 7,14 \\
\hline
\end{tabular}

Hasil analisis pada tabel 13 menunjukkan ada 26 responden $(92,86 \%)$ yang memiliki kontrol diri positif dan 2 responden $(7,14 \%)$ yang memiliki kontrol diri negatif.
Persentase Perubahan Kontrol Diri Klien Selama Mengikuti Terapi

Tabel 6. Distribusi Perubahan Kontrol Diri Setelah Pemberian Terapi

\begin{tabular}{llcc}
\hline \multirow{2}{*}{ No } & \multirow{2}{*}{ Hasil } & \multicolumn{2}{c}{ Post Test } \\
\cline { 3 - 4 } & & $\mathrm{f}$ & $\%$ \\
\hline 1 & Peningkatan & 26 & 92,86 \\
2 & Tetap & - & - \\
3 & Penurunan & 2 & 7,14 \\
\hline & Total & 28 & 100 \\
\hline
\end{tabular}

Menunjukan persentse perubahan kontrol diri subjek selama mendapatkan perlakuan, subjek yang mengalami peningkatan sebesar $92,86 \%$, tetap $0 \%$ dan penurunan $7,14 \%$. Hal ini menunjukkan bahwasanya pemberian perlakuan berhasil memberikan pengaruh yang positif terhadap kontrol diri subjek.

\section{Analisis Bivariat}

Dari 28 klien mendapatkan perlakuan selama 2 bulan melaksanakan shalat disertai dzikir sehari lima kali mulai dari subuh, dzuhur, ashar, magrib dan isya.

Tabel 7. Hasil Uji Beda Pengukuran Kontrol Diri (Mc Nemar)

\begin{tabular}{cccccccc}
\hline \multirow{2}{*}{ Kontrol diri } & \multicolumn{3}{c}{ Hasil Pengukuran } & & Total & $\%$ & Nilai $p$ \\
& Positif & $\%$ & Negatif & $\%$ & & & \\
\hline Pretest & 12 & 42,86 & 16 & 57,14 & 28 & 100 & \multirow{2}{*}{0.001} \\
Posttest & 26 & 92,86 & 2 & 7,14 & 28 & 100 & \\
\hline
\end{tabular}

Pada tabel 7 menjelaskan hasil uji beda pengukuran kontrol diri klien, pada pretest menunjukkan bahwa hasil pengukuran kontrol diri terdapat 16 responden yang memiliki kontrol diri negatif dan 12 responden memiliki kontrol diri positif dengan nilai median 82.50 dan nilai kontrol diri terendah 67 nilai tertinggi 102, kemudian setelah diberikan perlakuan terapi shalat disertai dzikir selama dua bulan hasil posttest menunjukkan bahwa hasil pengukuran kontrol diri terdapat 26 responden yang memiliki kontrol diri positif dan 2 responden yang memiliki kontrol diri negatif dengan nilai median 95.00 dan nilai kontrol diri terendah 65 tertinggi 116.

Uji statistik menggunakan Mc Nemar didapatkan nilai $\mathrm{p}<0.001$ yang lebih kecil dari nilai $\alpha 0.05$, berdasarkan hasil analisis Mc Nemar maka H0 ditolak dan Ha diterima, yang berarti terdapat pengaruh sebelum dan setelah pemberian terapi shalat disertai dzikir terhadap kontrol diri klien penyalahgunaan narkotika.

\section{PEMBAHASAN}

Faktor utama yang menyebabkan kecanduan narkoba sebagian besar disebabkan oleh kurangnya pendidikan dan lemahnya agama, spritual, rasa ingin tahu, gangguan depresi, masalah dalam keluarga, pengaruh pergaulan adanya gangguan kecemasan spesifik termasuk gangguan kecemasan umum, gangguan panik, dan gangguan stres pascatrauma semuanya telah dikaitkan dengan penggunaan narkoba yang terjadi bersamaan, dan interaksinya beragam 
dan bervariasi (Hadi, Rosyanti, \& Afrianty, 2018; Hadi, Wijayanti, Devianti, \& Rosyanti, 2017; Seghatoleslam et al., 2015; Zan \& Bethsaida, 2011).

Biasanya para pemakai semula hanya coba-coba karena ajakan teman, namun akhirnya menjadi ketagihan dan ingin mengkonsumsi terus. Para pemakai pada dasarnya tidak mengetahui dampak dari pemakaian narkoba, baik jangka panjang maupun jangka pendek, sehingga secara terus menerus mereka memakainya, bahkan mengajak teman-teman sebayanya untuk juga memakai narkoba. Efek dari pemakaian narkoba secara berkelanjutan akan menurunkan kesadaran, kekebalan tubuh, merusak hati, pikiran, bahkan bisa lebih parah lagi menyebabkan kematian dan penyakit sosial seperti tindak kriminal, perkelahian, perampasan dan tindak kekerasan lainnya.(Flynn et al., 2003; Rinaldi Eka Saputra, 2019).

Hasil dari penelitian artikel ini didapatkan kontrol diri positif meningkat pada pasien NAPZA yang diberikan terapi spritual shalat dan zikir. Peran bimbingan dan konseling Islam sangat dibutuhkan dalam menghadapi permasalahan masyarakat yang semakin kompleks. Salah satu permasalahan yang sering dihadapi yang menimbulkan dampak yang luas terhadap munculnya permasalahan adalah penggunaan dan pemakaian narkoba. Sehingga saat ini, para profesional kesehatan telah mulai meneliti nilai potensial dari keyakinan agama dan spiritualitas dalam kehidupan individu yang menderita berbagai penyakit akut, kronis dan mental. (Hawari, 1999; Rinaldi Eka Saputra, 2019; Rosyanti, Hadju, et al., 2018).

Penelitian ini di dukung oleh berbagai jenis studi penelitian yang telah dilakukan oleh beberapa ahli. Dalam sebuah Studi yang mengeksplorasi hubungan antara keyakinan agama, spiritualitas, dan hasil kesehatan mental pada 236 orang yang pulih dari penyalahgunaan zat, menemukan bahwa individu yang pulih cenderung melaporkan tingkat agama yang tinggi dan afiliasi agama, tetapi memilih untuk menilai diri mereka lebih spiritual dan beragama. Hasil tersebut juga menunjukkan bahwa di antara individu yang pulih, tingkat iman dan spiritualitas agama yang lebih tinggi dikaitkan dengan orientasi hidup yang lebih optimis, dukungan sosial yang lebih besar, ketahanan yang lebih tinggi terhadap stres, dan tingkat kecemasan yang lebih rendah (Pardini et al., 2000).

Dalam sebuah penelitia yang lain, faktor-faktor yang berkontribusi pada pemulihan jangka panjang dari ketergantungan narkotika diperiksa sebagai bagian dari studi tindak lanjut nasional selama 5 tahun terhadap 708 pasien dari 45 program perawatan di delapan kota di AS. Hasil dari 33\% dari sampel sangat baik pada tindak lanjut, termasuk tidak ada obat yang terdeteksi dalam spesimen urin atau rambut, tidak ada penggunaan obat yang dilaporkan sendiri, kurang dari penggunaan alkohol setiap hari, dan tidak ada kegiatan ilegal atau penangkapan selama setahun terakhir. Alasan utama yang dikutip untuk perbaikan ini adalah motivasi untuk berubah, pengaruh positif keluarga, kekuatan dari agama dan spiritualitas, dan bantuan dari perawatan narkoba. "Pemulihan" dipandang sebagai proses yang berkelanjutan dan merupakan manfaat dari pelajaran yang dipetik dalam perawatan. Atribusi retrospektif ini menegaskan banyak temuan yang sama dari studi hasil prospektif dan berkontribusi pada kerangka kerja konseptual untuk proses perawatan dan pemulihan (Flynn et al., 2003).

Narkotika yang digunakan secara terus menerus akan mengakibatkan toleransi yang cukup tinggi, dan jika pemakaian dihentikan maka akan menimbulkan with drawl atau sindroma putus zat. Gejala atau sindroma putus zat berbeda untuk setiap jenis zat yang digunakan, misalnya pada golongan opioida akan terjadi kejang perut, rasa tak enak, mual muntah, nyeri otot, sendi dan tulang, pupil melebar, berkeringat, diare, menguap, demam, insomnia dan gelisah. Pada extacy/amfetamin akan mengakibatkan 
lelah, mimpi buruk, insomnia, nafsu makan bertambah, gerakan lambat, murung, tindakan bunuh diri, depresi berat dan cemas (Hadi et al., 2018; Hadi et al., 2017; Zan \& Bethsaida, 2011).

Dalam sebuah penelitian eksplorasi pasie HIV-AIDS yang positif Narkoba, didapatkan 3 hal penting yang berhubungan dengan spritual yaitu : (a) bagaimana 'kerohanian' didefinisikan oleh pengguna narkoba HIV-positif; (B) hubungan yang dirasakan antara spiritualitas dan kontrol diri, pengurangan bahaya, dan promosi kesehatan; dan (c) menilai minat dalam intervensi berbasis spiritualitas. Pasien yang tergantung opioid yang terdaftar dalam program perawatan metadon dalam kota berpartisipasi dalam penelitian ini; 21 berpartisipasi dalam kelompok fokus dan 47 mengisi kuesioner. Dalam kelompok fokus, muncul dua tema utama: spiritualitas sebagai sumber kekuatan/ perlindungan diri, dan spiritualitas sebagai sumber altruisme/perlindungan orang lain. Sebagian besar sampel menyatakan minat untuk menerima perawatan yang berfokus pada spiritualitas, melaporkan bahwa intervensi semacam itu akan membantu untuk mengurangi keinginan dan perilaku berisiko HIV-AIDS, mengikuti rekomendasi medis, dan meningkatkan harapan (Arnold et al., 2002; Dermatis, Guschwan, Galanter, \& Bunt, 2004).

Dalam penelitian negara hongaria, Sejumlah faktor risiko telah muncul sebagai korelasi penting dari penggunaan narkoba. Salah satu faktor pelindung adalah religiusitas dan perannya dalam kehidupan di Hongaria postocialist, di mana partisipasi keagamaan aktif sangat tidak dianjurkan sampai satu dekade yang lalu. Sampel remaja $(\mathrm{N}=1240)$ terdiri dari siswa sekolah menengah dan tinggi yang tinggal di Szeged, Hongaria. Odds Rasio yang dihitung untuk hubungan antara religiusitas, dan faktorfaktor pelindung lainnya, dan penggunaan narkoba mengungkapkan bahwa merokok, minum, dan penggunaan ganja di kalangan anak laki-laki dan penggunaan ganja hanya di kalangan anak perempuan terkait dengan religiusitas. Keanggotaan grup, partisipasi dalam klub sekolah, klub olahraga, atau kelompok agama, lebih penting untuk anak laki-laki dan anak perempuan (Piko \& Fitzpatrick, 2004).

Doa harian yang disebut Shalat dalam bahasa Arab adalah tindakan ibadah yang spesifik dan unik bagi Islam baik dalam bentuk maupun semangatnya. Sementara kata doa dalam bahasa Inggris menyampaikan makna umum permohonan atau doa, Shalat adalah tindakan penyerahan kepada Maha Pencipta Allah dan dinyatakan dalam tindakan fisik yang spesifik dan didefinisikan dengan baik yang mewujudkan roh. Tindakan ibadah ini ditahbiskan pada semua Muslim sebagai kewajiban dan merupakan pilar kedua dari iman. Sementara sholat lima waktu yang ditentukan adalah wajib bagi semua individu pasca pubertas sebagaimana diperintahkan dalam Kitab Suci "Sesungguhnya, Sholat adalah kewajiban bagi orang-orang beriman untuk diamati pada waktu yang ditentukan." (Qur'an 4: 103), doa sukarela di kelebihan di atas sangat dianjurkan dan direkomendasikan sebagai cara untuk beralih ke bantuan ilahi pada saat kesedihan dan kesusahan pribadi (Baqi \& Fu'ad, 2012; Kibtyah, 2017; Muflih, 2013; Sayeed \& Prakash, 2013).

Bentuk ibadah kedua yang disebut Zikr, yang berarti meditasi adalah tindakan individu mengingat Allah setiap saat untuk memuliakan-Nya dan tetap bersyukur atas kemurahan dan kebaikan-Nya. Melalui kedua cara ini individu Muslim mencari kedekatan dengan Sang Pencipta dan mencapai kedamaian dan ketenangan batin yang paling dikenal Allah sebagai ciptaanNya dan dengan demikian mengatakan dalam Al Qur'an "Sesungguhnya, manusia diciptakan tidak sabar, mudah tersinggung ketika kejahatan menyentuh dia dan dengan kasar ketika kebaikan menyentuhnya. Kecuali bagi mereka yang mengabdikan diri untuk berdoa, mereka yang tetap konstan dalam doa-doa mereka..." (70: 19-23). 
Melalui kedua cara ini individu Muslim mencari kedekatan dengan Sang Pencipta dan mencapai kedamaian dan ketenangan batin yang paling dikenal Allah sebagai ciptaan-Nya dan dengan demikian mengatakan dalam Al Qur'an "Sesungguhnya, manusia diciptakan tidak sabar, mudah tersinggung ketika kejahatan menyentuh dia dan dengan kasar ketika kebaikan menyentuhnya. Kecuali bagi mereka yang mengabdikan diri untuk berdoa, mereka yang tetap konstan dalam doa-doa mereka ..." (70: 19-23). (Al-Ghazal, 2013; Baqi \& Fu'ad, 2012; Hussein; Muflih, 2013; Rosyanti et al., 2019).

Melalui kedua cara ini individu Muslim mencari kedekatan dengan Sang Pencipta dan mencapai kedamaian dan ketenangan batin yang paling dikenal Allah sebagai ciptaan-Nya dan dengan demikian mengatakan dalam Al Qur'an "Sesungguhnya, manusia diciptakan tidak sabar, mudah tersinggung ketika kejahatan menyentuh dia dan dengan kasar ketika kebaikan menyentuhnya. Kecuali bagi mereka yang mengabdikan diri untuk berdoa, mereka yang tetap konstan dalam doa-doa mereka ..." (70: 19-23).(Al-Ghazal, 2013; Muflih, 2013; Rosyanti et al., 2019; Rosyanti, Hadju, et al., 2018; Syed, 2003).

Sebagai rukun Islam kedua, Shalat dilakukan oleh semua Muslim di seluruh dunia dengan cara dan ukuran yang persis sama, setidaknya lima shalat wajib. Langkah-langkah dan permohonan khusus ditunjukkan dengan contoh oleh Nabi Suci Muhammad (SAW) sebagaimana disebutkan dalam Hadis ini "Berdoa seperti yang Anda lihat saya berdoa dan ketika saatnya untuk shalat salah satu dari Anda harus mengucapkan adzan dan yang tertua dari Anda harus memimpin doa" (Sahih Bukhari-Buku 11: Panggilan untuk salat; Hadits 604). Untuk menyadari dampak yang luas jangkauannya dan mendalam pada sikap, perilaku dan kehidupan seorang Mukmin harus dipahami dengan benar dan dilaksanakan dengan tepat seperti yang diberikan dalam teks otentik.(Qutub, 2011;
Sabry \& Vohra, 2013; Sayeed \& Prakash, 2013).

Pengalaman dzikir ini mampu memberikan pencerahan bagi jiwa-jiwa yang kering dan gersang menjadi jiwa yang penuh optimisme. Shalat yang khusyu' dapat memberikan ketenangan mental dan menghilangkan ketegangan degan beberapa alasan. Diantaranya adalah munculnya perasaan seseorang bahwa seluruh permasalahan yang ia hadapi menjadi pudar ketika ia berada dihadapan kekuatan yang maha Agung, yaitu Allah yang maha pencipta dan maha mengatur seisi alam semesta. Maka ketika seseorang teah selesai dari shalatnya, ia akan merasa bahwa segala permasalahannya sudah menemukan jalan keluar dan akan diselesaikan oleh Allah yang maha penyayang. (Amin \& Al-Fandi, 2008; Haryanto \& Samsul, 2008; Hawari, 1999; Kahfi \& Rosiana, 2013; Rinaldi Eka Saputra, 2019; Rosyanti, Hadju, et al., 2018).

\section{KESIMPULAN DAN SARAN}

Melihat dari banyaknya manfaat shlat dan dzikir bagi kesehatan mental, sehingga sesuai dengan hasil dalam penelitian ini, terdapat pengaruh yang signifikan dalam bentuk shalat disertai dzikir terhadap kontrol diri klien penyalahgunaan narkotika dengan nilai $\mathrm{p}$ value $<0,001$ yang lebih kecil dari nilai $\alpha 0.05$, Hal ini menunjukan bahwa perlakuan berupa terapi kompelenter mind body therapy dalam bentuk shalat disertai dzikir dapat meningkatkan kontrol diri klien penyalahgunaan narkotika.

Shalat dan dzikir sebagai bentuk terapi untuk meningkatkan pengendalian diri klien penyalah gunaan narkotika, dengan maksud ketika berhasil meningkatan kontrol diri klien penyalah gunaan narkotika nantinya klien akan mampu mengendalikan dirinya dari pemakaian narkotika dan sehat dan normal kembali. Shalat yang khusyu' dapat memberikan ketenangan mental dan menghilangkan ketegangan. Terapi shalat dan dzikir terbukti mampu membuat pikiran subjek menjadi lebih tenang, lebih mampu 
mengontrol emosi dan pikiran, keinginan subjek untuk mengkonsumsi narkotika menurun.

Saran, terapi ini bisa dijadikan bentuk terapi utama pada lembaga rehabilitasi narkoba. Bagi peneliti selanjutnya yang ingin meneliti tentang hal ini, dapat dikembangakn dengan jumlah pasien yang lebih banyak, kasus berbeda dan terapi tambahan seperti puasa, doa, shalat sunnah dll. Bagi masyarakat islam khususnya untuk mengamalkan dan aplikasikan ajaran agama dalam kehidupan sehari-hari terutama mendirikan shalat, berzikir, membaca alquran dan berakhlak mulia agar terbebas dari segala penyakit mental, fisik dan kecanduan Napza.

\section{DAFTAR PUSTAKA}

Al-Ghazal, S. K. (2013). Medical Miracles Of The Qur'an: Kube Publishing Ltd.

Amin, S. M., \& Al-Fandi, H. (2008). Energi Dzikir: Menentramkan Jiwa Membangkitkan Optimisme.

Ardani, M. (2008). Fikih Ibadah Praktis: Bumbu Dapur Communication.

Arnold, R., Avants, S. K., Margolin, A., \& Marcotte, D. (2002). Patient Attitudes Concerning The Inclusion Of Spirituality Into Addiction Treatment. $J$ Subst Abuse Treat, 23(4), 319-326. Doi:10.1016/S0740-5472(02)00282-9

Averill, J. R. (1973). Personal Control Over Aversive Stimuli And Its Relationship To Stress. Psychological Bulletin, 80(4), 286.

Baqi, M. F. A. A., \& Fu'ad, M. (2012). Al-Lu'lu Wal Marjan Kumpulan Hadist Shahih Bukhari Muslim. Solo: Insan Kamil.

Cook, C. C. (2004). Addiction And Spirituality. Addiction, 99(5), 539-551. Doi:10.1111/J.13600443.2004.00715.X

Dermatis, H., Guschwan, M. T., Galanter, M., \& Bunt, G. (2004). Orientation Toward Spirituality And Self-Help Approaches In The Therapeutic Community. $J$ Addict Dis, 23(1), 39-54. Doi:10.1300/J069v23n01 04

Fiorentine, R., \& Hillhouse, M. P. (2000). Drug Treatment And 12-Step Program Participation: The Additive Effects Of Integrated Recovery Activities. J Subst
Abuse Treat, 18(1), 65-74. Doi:10.1016/S0740-5472(99)00020-3

Flynn, P. M., Joe, G. W., Broome, K. M., Simpson, D. D., \& Brown, B. S. (2003). Looking Back On Cocaine Dependence: Reasons For Recovery. American Journal On Addictions, 12(5), 398-411.

Ghufron, M. N., \& Risnawita, R. (2010). TeoriTeori Psikologi. Yogyakarta: Ar-Ruzz Media.

Hadi, I., Rosyanti, L., \& Afrianty, N. S. (2018). Tingkat Kecemasan Narapidana Wanita Di Lapas Kendari Dengan Kuisioner Taylor Manifest Anxiety Scale (Tmas). Health Information: Jurnal Penelitian, 10(2), 23-27.

Hadi, I., Wijayanti, F., Devianti, R., \& Rosyanti, L. (2017). Gangguan Depresi Mayor (Mayor Depressive Disorder) Mini Review. Health Information: Jurnal Penelitian, 9(1), 25-40.

Haryanto, A., \& Samsul, M. (2008). Energi Dzikir Menentramkan Jiwa Membangkitkan Optimsme. Amzah, Wonosobo.

Hawari, D. (1999). Ilmu Kedokteran Jiwa Dan Kesehatan Jiwa. Yogyakarta: Dana Bhakti Primayasa.

Heinz, A. J., Disney, E. R., Epstein, D. H., Glezen, L. A., Clark, P. I., \& Preston, K. L. (2010). A Focus-Group Study On Spirituality And Substance-User Treatment. Substance Use \& Misuse, 45(1-2), 134-153. Doi:10.3109/10826080903035130

Hidayati, N. (2014). Peningkatan Hasil Belajar Fiqih Materi Zikir Setelah Shalat Fardhu Melalui Strategi PracticeRehearsal Pairs Pada Siswa Kelas Ii A Madrasah Ibtidaiyah Nahdlatul Ulama (Minu) Wedoro Sidoarjo. Uin Sunan Ampel Surabaya.

Hussein, B. Hadist Sahih Bukhari. Muslim: Surabaya: Cv Karya Utama.

Kahfi, A. S., \& Rosiana, D. (2013). "Religiousness Islami" Dan "Self Regulation" Para Pengguna Narkoba. Mimbar, Jurnal Sosial Dan Pembangunan, 29(1), 77-84.

Khalid, M. Y. (2008). Psychospiritual Therapy Approach For Drug Addiction Rehabilitation. Jam,(3), 143-151.

Kibtyah, M. (2017). Pendekatan Bimbingan Dan Konseling Bagi Korban Pengguna 
Narkoba. Jurnal Ilmu Dakwah, 35(1), 52-77.

Maisto, S. A., \& Caddy, G. R. (1981). SelfControl And Addictive Behavior: Present Status And Prospects. International Journal of The Addictions, 16(1), 109-133. Doi:10.3109/10826088109038814

Mcdowell, D., Galanter, M., Goldfarb, L., \& Lifshutz, H. (1996). Spirituality And The Treatment Of The Dually Diagnosed: An Investigation Of Patient And Staff Attitudes. J Addict Dis, 15(2), 55-68. Doi:10.1300/J069v15n02_05

Miller, W. R. (1998). Researching The Spiritual Dimensions Of Alcohol And Other Drug Problems. Addiction, 93(7), 979-990.

Mudzkiyyah, L., Nashori, F., \& Sulistyarini, R. I. (2014). Terapi Zikir Al-Fatihah Untuk Meningkatkan Kesejahteraan Subjektif Pecandu Narkoba Dalam Masa Rehabilitasi. Jurnal Intervensi Psikologi, 6(2).

Muflih, A. (2013). Pengobatan Dalam Islam. Universitas Islam Negeri Alauddin Makassar.

Nęcka, E. (2015). Self-Control Scale As-36: Construction And Validation Study. Polish Psychological Bulletin, 46(3), 488-497.

Osama, M., \& Malik, R. J. (2019). Salat (Muslim Prayer) As A Therapeutic Exercise. Jpma. The Journal Of The Pakistan Medical Association, 69(3), 399-404.

Pardini, D. A., Plante, T. G., Sherman, A., \& Stump, J. E. (2000). Religious Faith And Spirituality In Substance Abuse Recovery: Determining The Mental Health Benefits. $J$ Subst Abuse Treat, 19(4), 347-354. Doi:10.1016/S07405472(00)00125-2

Piedmont, R. L. (2004). Spiritual Transcendence As A Predictor Of Psychosocial Outcome From An Outpatient Substance Abuse Program. Psychology Of Addictive Behaviors, 18(3), 213.

Piko, B. F., \& Fitzpatrick, K. M. (2004). Substance Use, Religiosity, And Other Protective Factors Among Hungarian Adolescents. Addict Behav, 29(6), 10951107.

Doi:10.1016/J.Addbeh.2004.03.022

Qutub, S. (2011). Sumber-Sumber Ilmu Pengetahuan Dalam Al Qur'an Dan Hadits. Humaniora, 2(2), 1339-1350.
Rinaldi Eka Saputra, S. (2019). Pemikiran Dadang Hawari Tentang Psikoterapi Islam Dalam Penanggulangan Korban Penyalahgunaan Narkotika, Psikotropika, Zat Adiktif Dan Relevansinya Dengan Pengembangan Masyarakat Islam. Uin Raden Intan Lampung.

Rosyanti, L., Hadi, I., Tanra, J., Islam, A., Hatta, M., Hadju, V., . . Ibrahim, K. (2018). The Effectiveness Of Spiritual Qur'anic Emotional Freedom Technique (Sqeft) Intervence Against The Change Of Brief Psychiatric Rating Scale (Bprs) On Patient With Schizophrenia. Health Notions, 2(8), 895-900.

Rosyanti, L., Hadi, I., Tanra, J., Islam, A., Natzir, R., Massi, M. N., \& Bahar, B. (2019). Change Of Brief Psychiatric Rating Scale (Bprs) Value With Spiritual Qur'anic Emotional Freedom Technique (Sqeft) Therapy On Mental Disorder Patient. Indian Journal of Public Health Research \& Development, 10(1).

Rosyanti, L., Hadju, V., Hadi, I., \& Syahrianti, S. (2018). Pendekatan Terapi Spiritual Al-Quranic Pada Pasien Skizoprenia Tinjauan Sistematis. Health Information: Jurnal Penelitian, 10(1), 39-52.

Sabry, W. M., \& Vohra, A. (2013). Role Of Islam In The Management Of Psychiatric Disorders. Indian Journal Of Psychiatry, 55(Suppl 2), S205-S214. Doi:10.4103/0019-5545.105534

Sayeed, S. A., \& Prakash, A. (2013). The Islamic Prayer (Salah/Namaaz) And Yoga Togetherness In Mental Health. Indian Journal Of Psychiatry, 55(Suppl 2), S224-S230.

Doi:10.4103/00195545.105537

Seghatoleslam, T., Habil, H., Hatim, A., Rashid, R., Ardakan, A., \& Esmaeili Motlaq, F. (2015). Achieving A Spiritual Therapy Standard For Drug Dependency In Malaysia, From An Islamic Perspective: Brief Review Article. Iranian Journal Of Public Health, 44(1), 22-27. Retrieved From Https://Www.Ncbi.Nlm.Nih.Gov/Pubm ed/26060772

Https://Www.Ncbi.Nlm.Nih.Gov/Pmc/ Articles/Pmc4450010/ 
Suhardi, K. (2002). Edisi Indonesia: Syarah Hadist Pilihan Bukhari Muslim: Jakarta: Darul Falah.

Syabiq, S. Fiqh Sunnah, Diterjemahkan Oleh Mujahidin Muhayyan Dari” Fiqhus Sunnah", Jakarta: Pena Pundi Aksara, 2010, Jilid V. Cet. Ii.

Syed, I. B. (2003). Spiritual Medicine In The History Of Islamic Medicine. $J$ Int Soc History Islamic Med, 2(1), 45-49.

\section{UCAPAN TERIMAKASIH}

Tim penulis mengucapkan terima kasih kepada manajemen Lapas Kelas II A Kendari atas kesempatan dan bimbingan yang telah diberikan.

\section{INFORMASI TAMBAHAN}

\section{Lisensi}

Hakcipta (c) 2019 Health Information : Jurnal Penelitian
Unger, A., Bi, C., Xiao, Y. Y., \& Ybarra, O. (2016). The Revising Of The Tangney Self-Control Scale For Chinese Students. Psych Journal, 5(2), 101-116.

Zan, P. H., \& Bethsaida, J. (2011). Pengantar Psikopatologi Untuk Keperawatan. Kencana Prenada Media Group. Jakarta.

artikel akses terbuka ini dapat disebarkan seluas-luasnya sesuai aturan Creative Commons Attribution-ShareAlike 4.0 International License dengan catatan tetap menyebutkan penulis dan penerbit sebagaimana mestinya.

Catatan Penerbit: Poltekkes Kemenkes Kendari menyatakan tetap netral sehubungan dengan klaim dari perspektif atau buah pikiran yang diterbitkan dan dari afiliasi institusional manapun. 